\title{
Bullying at work: A comprehensive definition and consequences based on an empirical study
}

\author{
Ambreen Anjum (correspondence author) \\ Department of Applied Psychology, The Islamia University of Bahawalpur, Pakistan \\ E-mail: aambreenaanjum@hotmail.com
}

Kausar Yasmeen

Department of Economics, The Islamia University of Bahawalpur, Pakistan

Ph:+92 300899 5083, Email: eco.yasmeen@gmail.com

Kashifa Yasmeen

Department of Applied Psychology, The Islamia University of Bahawalpur, Pakistan

Ph: +92 03007722474, E-mail: kahsifa.hasan@yahoo.com

Accepted: August 28, 2011 DOI: 10.5296/ijhrs.v1i1.907

\begin{abstract}
This paper determines a comprehensive definition of workplace bullying and explores its job-related consequences. In the present study multi- methods approach was used which consist of questionnaire and in depth interviews. Interview was used in order to investigate perception and experience of workplace bullying and questionnaire to explore the consequences of workplace bullying. Results show bullying involves negative behaviors e.g. harassing, socially excluding someone and/or negatively effecting someone's work tasks, which occurs frequently and continues for period of time and victim is not only unable to control these acts but also suffer in severe health and job related consequences.
\end{abstract}

Keywords: Bullying, job-related consequences, Negative acts 


\section{Introduction}

Workplace Bullying is a widespread phenomenon in working life with high cost to both employee victim and organization itself (Glendinning, 2001). During the past decade, bullying at workplace has been devoted increasing public interest, debate and research (Strandmark \& Hallberg, 2007). It has become a dilemma that is too expensive to ignore .According to Duffy and Sperry (2007)bullying results in the humiliation, degradation, devaluation, loss of professional reputation and, usually the elimination of the target from the organization with all the concomitant, financial, career, health and psychological implications that one might expect from a protracted traumatizing experience.

The aim of present research is not only to provide an opportunity to understand the comprehensive nature of phenomenon with vivid /comprehensive illustration of work place bullying behaviors and its consequences its job related consequences.

\section{Context of the study}

There is no any agreed and complete definition of workplace bullying. (Rayner, 1999; Quine, 1999; Ryner \& Hoel, 1997). According to Zapf and Einarsen (2001) labeling of behavior as bullying is arbitrary and differs between countries and researchers. One possible cause of this arbitrary nature is conflict in terms and definitions. This definition proliferation hinders our ability to conceptualize the phenomenon of workplace bullying in clear and consistent way, and obscure affective collaboration among researchers \& practioners. To understand the full nature of phenomenon we must take care to collaborate regarding its terms and definition. This collaboration will support in the development of a standard nomenclature to facilitate employers and legislatures for the development of intervention strategies.

Various terms are used to describe the phenomenon e.g

Workplace Bullying (Adam and Crawford, 1992), Harassment (Bjorkqvist et al, 1994), Workplace aggression (Baron and Neuman, 1998), workplace Victimization (Zapf, 1999), Mobbing (Layman, 1990: Zapf el al, 1996), Perceived victimization (Aquino \& Bradfield, 2000). Aggression (Nansel et al, 2001), Workplace abuse (Keashly, 1998), Workplace harassment (Broadsky 1976) etc.

Like terms, another most persistent and troubling dilemma in the literature on workplace bullying has been the lack of a generally agreed upon operational definition, one that could be used in research and theory construction. Although many studies have been conducted, each has tended to develop its own methodology, a practice yielding conflicting presumes of incidence rates and behaviors. This has not only led to disarray in the literature but also reduced the credibility of workplace bullying reports within the legal system.

The majority of definitions of workplace bullying are priori in nature; that is, rather than being explicitly data based, they are derived from theoretical propositions concerning the nature of the construct. These kinds of definitions take one of the two types. Form one consists of a general statement telling the nature of phenomena (workplace bullying) and (sometime) describes about the persons who are involved. Second form reveals the list of 
specific actions, with no formal explication of the theoretical framework from which such a list is derived, with a general exception that the behavior is usually explained as unwanted by the victim.

Empirical definitions of bullying are derived by asking employee directly if they have been bullied, and if so, to describe their experiences. Thus this qualitative data are then content analyzed, and a comprehensive classification scheme is developed.

\section{Literature Review}

Concept of bullying may be used in many situations describing a variety of behaviors. According to kashly (1998) such behaviors mostly involved of a verbal nature and seldom include physical violence. In a study among Norwegian sample, where $88 \%$ had experienced some form of verbal bullying during the last six months, only $2.4 \%$ showed having been subjected to physical treats of such abuse (Einarsen et al,1994). According to Laymann(1990) behavior involved in bullying are in fact very common in every day life. However, they may cause much harm when occurring on a regular basis. Niedl (1995) argues that a victim will perceive repeated and aggressive behavior as bullying if the behavior is perceived as being hostile, directed towards oneself where the victim is unable to defend himself.

According to many studies (e.g. Einarsen et al,1994) manager and supervisors are seen as bullies in number of cases. So power is the major element of bullying.

There is a strong relationship between bullying and vocational strains. According to researches being exposed to heavy workloads and tight or impossible deadlines may cause elevated level of stress among workers which is ultimately harmful for organizations.

Absenteeism is an alarming issue of organizations. Researchers describe one of the major reason of absenteeism is workplace bullying. According to studies high level of absenteeism is noted in the result of stressful working condition.

According to number of studies high turn over rate is a major consequence of bullying at workplaces. Zapf et al (1996) says that $82 \%$ of employee left their workplace just because of workplace bullying. All organizations spend a lot on their employees in terms of induction and training. So, employee turnover is highly expensive for organizations. It id noted that workers have strong wish to be informed; when important information are withheld result is high turnover. According to studies organizations with strong communication system enjoy with lower turn over rate of employees.

Low productivity is another problem occurs because of workplace bullying. According to researchers says that employees are highly crucial to organization. Therefore, boss or supervisor must understand that workers as most important contributors to the efficient achievement of the organization success. 


\section{Research objectives}

- To determine the exact nature of workplace bullying phenomenon.

- To examine the kinds of workplace bullying.

- To explore the duration of workplace bullying.

- To search the source of workplace bullying.

- To explore the job related consequences of workplace bullying

\section{Methodology}

The core objectives of the study were to determine the exact nature of workplace bullying and its consequences. So for this purpose combination of qualitative and quantitative approach was used which consist of questionnaire in order to get primary data regarding elements of workplace bullying and consequences and interviews in order to study thorough perception of employees regarding the nature of workplace bullying.

The sample size determined by researcher was 50, belonging to different organizations (e.g. university, banks, private offices, court and hospitals) of Bahawalpur, Pakistan.50valid questionnaires were analyzed. Moreover, in order to enhance the reliability of present research, in depth interviews have also been conducted from 20 employees belonging to different above mentioned organizations.

\section{Findings}

Tale: 1

\begin{tabular}{|l|l|l|}
\hline Organization & Frequency & Percentage \\
Banks & 10 & $20 \%$ \\
University & 20 & $40 \%$ \\
Hospitals & 10 & $20 \%$ \\
Private offices & 5 & $10 \%$ \\
Courts & 5 & $10 \%$ \\
Gender & & \\
Male & 22 & $44 \%$ \\
Female & 28 & $56 \%$ \\
Age & & \\
$20-30$ & 30 & $60 \%$ \\
$31-40$ & 10 & $20 \%$ \\
$41-50$ & 10 & $20 \%$ \\
Educational level & 25 & $50 \%$ \\
Bachelor & 25 & $50 \%$ \\
Masters and above & & $60 \%$ \\
Work experience & & $24 \%$ \\
$1-5$ & 30 & \\
$6-10$ & & \\
\hline
\end{tabular}




\subsection{Nature of workplace bullying}

Discussing the nature of workplace bullying, Majority of workers believe it is specific type of behavior in which one conceals important information, as results of the survey shows that $40 \%$ of respondents report their boss and co-workers withhold information which effects their work performance. 30\%respondents report that their boss repeatedly checks their work and even the completion of important assignments never appreciate.50\% workers said that their boss not only devalue their work but also assigns such type of tasks which clearly fall outside their job description.30\% employees report that their co-workers and sub ordinates spread rumors about their personal life, As one nurse said that

"I have been serving in this hospital for the last five years and almost every week I listen one new rumor about my personal life”

Furthermore, talking about the negative acts at workplace, an assistant professor said that

"My chairman never values my opinion or views. Even I receive hostile answer of my questions"

Another bank employee report that

"My boss assigns me tasks with impossible deadlines"

\subsection{Source of workplace bullying}

The response of the questionnaire statement" who is the source of bullying" four options were given one "boss" second "co-worker" third "subordinate” and fourth "All”. 60\% of employees report it boss, 20\% answer it co-worker, 10\% report it subordinate and others said all three are the source of workplace bullying. So, according to the survey in most cases boss involves in workplace bullying .According to the studied one important cause behind this is authority or the power which he has. Moreover, in such cases where boss is a perpetrator, it becomes difficult for victim to defend himself. Another important finding of present research is that more than one people may involve in bullying(table: 2). when researcher inquired "Do you think perpetrator has an intention of bullying behavior?” 94\% workers clearly mentioned that perpetrators very well know about their actions(table: 3)as one lawyer said that

“Perpetrators not only know about their negative behavior but they also work on it”. 
Table: 2

Who is the source of bullying?

\begin{tabular}{|lcc|}
\hline Source & Frequency & Percentage \\
\hline Boss & 30 & $60 \%$ \\
\hline Co-worker & 10 & $20 \%$ \\
\hline Subordinate & 5 & $10 \%$ \\
\hline All & 5 & $10 \%$ \\
\hline
\end{tabular}

Source: survey data

Table: 3

Do you think perpetrator has an intention of bullying behavior?

\begin{tabular}{|lcc|}
\hline Options & Frequency & Percentage \\
\hline Yes & 47 & $94 \%$ \\
\hline No & 3 & $6 \%$ \\
\hline
\end{tabular}

Source: survey data

\subsection{Duration of workplace bullying}

The response of the questionnaire statement" How often your boss, co-worker and/or subordinate show negative behavior" 72\% report such type of behaviors occur on weekly basis or twice in a weak. So, result shows victim persistently face negative behaviors.

\subsection{Consequences of workplace bullying}

Both Employees and organizations are facing number of problems because of workplace bullying. Discussing these problems majority (70\%) of the workers report that they are not satisfied with their jobs (Table: 4). More over, 62\% (Table: 5) of employee said that they want to change their jobs because of high workload and unjustified criticism. As one lecture said that

"My chairman always criticizes my work. I am sick of this stressful environment and I want to change my job as much as possible”

Another employee said that

"Because of these negative acts I try to avoid going my office regularly". 


MlMacrothink

Table:4

Are you satisfied with your job?

\begin{tabular}{|lcc|}
\hline Options & frequency & Percentage \\
\hline Yes & 35 & $70 \%$ \\
\hline No & 15 & $30 \%$ \\
\hline
\end{tabular}

Source: survey data

\section{Table:5}

Do you want to change your job?

\begin{tabular}{|lcc|}
\hline Option & Frequency & Percentage \\
\hline Yes & 31 & $62 \%$ \\
\hline No & 19 & $38 \%$ \\
\hline
\end{tabular}

Source: survey data

It was also observed that employees of such organizations are less motivated. As one employee expressed that

"I suffer from lack of interest towards my office work. I feel interruption in my work”.

\section{Findings and Conclusion}

Findings of present study shows

1-Negative act(s) concerning work related (withhold information, excessive monitoring), personal life(spreading gossips and rumors),social life(devaluation of opinion and views, exclusion from group activities),physical violence( threats and attacks) is called workplace bullying .

2- One or more individual may involve in workplace bullying.

3- Perpetrator(s) are very well aware of his negative actions.

4-Bullying occurs regularly and persistently.

5-Authority is one of the most important factors in the occurrence of workplace bullying.

6- Low motivational level, Absenteeism, high turn-over and low job satisfaction are the most important consequences of workplace bullying. 
There is still a considerable need for empirical studies on the nature of bullying at work.

\section{References}

Adams, A., Crawford,N.(1992). Bullying at work: How to confront and overcome it.London: virago press.

Aquino,K.,\&Bradfield,M.(2000).Percieved victimization in the workplace:the role of situational factors and victim characterics.Organization science,11(5),525-537.

Bjorqvist, K., Osterman, K., \&Hjelk-Back, M. (1994) Aggression among university employees.Aggressive behavior.20,173-184.

Baron,R.A., Neuman, J.H. (1996). Work place violence and workplace aggression:evidence on their relative frequency and potential causes Aggressive behavior, 22,161-73.

Duffy, M. K., \& Sperry, L. (2007) workplace Mobbing: individual and family health consequences. The family journal: counseling and therapy for couples and families. 15(4) 398-404.

Einarsen, S., Raknes, B. I., \&Matheisen, S. B. (1994): Bullying and harassment at work and their relationships to work environment quality: An exploratory study. The European work and organization psychologist.4,381-401.

Glendinning, P.(2001). Workplace bullying curing the cancer of the American workplace.Public personnel management, 30(3), 269-286.

Keashly, L. (1998). Emotional abuse in the workplace: Conceptual and empirical issues. Journal of emotional abuse, 1(1),85-117.

Laymann,H.(1990). Mobbing and psychological terror at workplaces.Violence and victim,5,119-26.

Niedl, K. (1996). Mobbing and well being: Economic and personal development implications. European Journal of work and organizational psychology 5,239-249.

Nansel,T., Overpeck,R., Pilla,W., Ruan,P.,Scheidt,K.,\& Simons-Morton,B.(2001).Bullying behaviors among USyouth: Prevalence and association with psychological adjustment. Journal of the American medical association ,285,2094-2100

Quine, L. (1999). Workplace bullying in NHS community trust: staff questionnaire survey. British medical journal, 318, 228-232

Rayner, C., Sheehan, M., \&Barker, M.(1999).Theoretical approaches to the study of bullying at work. International journal of manpower,20,11-15.

Rayner, C., \&Hoel, H.(1997).Workplace bullying: Myth or reality-can we afford to ignore it? Leadership and organizational development journal,18,211-214

Strandmark, K.M., \&Holloerg, L.R.M. (2007). The origin of workplace bullying: Experiences from the perspective of bully. Victims in the public service sector, journal of nursing 


\section{Macrothink \\ International Journal of Human Resource Studies \\ ISSN 2162-3058 \\ 2011, Vol. 1, No. 1}

management 15, 332-341.

Zapf, D. (1999). Organizational, work Group related and personal causes of mobbing bullying at work. International journal man power 20,70-85.

Zapf, D., \&Einarsen, S.(2001).Bullying in the workplace: Recent trends in research and practice- an introduction. European journal of work and organizational psychology, 10,369-373.

Zapf, D., Knorz, C.,\&Kulla , M.(1996).On the relationship between mobbing and bullying at work.international journal of manpower,5,215-37. 